\title{
Exploring translator disparity
}

\author{
B. O. Pliushch \\ Assistant Professor, Taras Shevchenko National University of Kyiv, Kyiv, Ukraine \\ Corresponding author. E-mail: danapliushch@outlook.com \\ Paper received 25.05.18; Accepted for publication 03.06.18.
}

\section{https://doi.org/10.31174/SEND-Ph2018-166VI49-09}

\begin{abstract}
The article focuses on translator disparity as a notion inherent to the translation of the so-called small literatures. It considers the role of a translator disparity in the representation of Ukrainian literary prose as well as explores its correlation with other marginal translation practices such as indirect translation. Ukrainian literature represents an illustrative material of this article since Ukrainian does not belong to the range of widespread languages and is rarely learned as a foreign language by English native speakers.

Keywords: translation, translator disparity, indirect translation, translator ethics, agent of translation, translator's responsibility, paratexts.
\end{abstract}

Literary translation has always been the source of inspiration for many metaphors about translation in general. Belles infidèles, "traduttore, traditore", bridging cultures etc. Although nowadays most of them are either criticized, or justified by different scholars and translators, it stands to reason that the issues it raises will always be contentious as well as the process of translation will always be indeterminant. Translation of the literary prose into any of the European languages contributes to the formation of its countries image within the cultural space of Europe. Thus, literary translation is extremely important sector of cultural branding. Ukrainian literary translations are no exception.

Ukrainian belongs to "small" [3, p.53] or peripheral languages. Thus, translations from Ukrainian are quite rare. Their dynamics can be characterized as chaotic, selective, missionary/ volunteer etc. Their disctinctive feature is the implication of the mere fact of any literary work translated from Ukrainian is quite an "achievement". Hence, translator disparity, which denotes inequality of translation conditions, requirements to the translator, translation pact $[1, \mathrm{p}$. 271] and translator responsibility [9, p. 56] etc. This inequality takes place in the translation situation where the source literature is considered to be "small". Ukrainian would be the case. Literary works by Ukrainian authors were very often translated into other languages through the intermediary language - Russian (mainly works by Ivan Franko (e.g. "Boa Constrictor"), I. Bahriany etc.). However, in view of legal standards and other factors, the cases of indirect translations were usually concealed. Thus, the real number of the indirect translations of the Ukrainian prose remains to be seen. Another intermediary language, used for the translation of the Ukrainian literature, was (and still is) English (e.g. the novel "Tyhrolovy" by Ivan Bahriany was indirectly translated into German, Dutch, Italian etc.). The concealment of indirect translation is connected to the legal aspect of translation (UNESCO Recommendation on the Legal Protection of Translators and Translations and the Practical Means to improve the Status of Translators) and the ideological motives (in the past, at least).

One of the implications of translator disparity in terms of Ukrainian prose translation is its indirect translation. In our previous studies, we have established that the main causes for such a longstanding practice of the indirect translation are the "rarity" of the source language and unacceptability of L 2 translation (translation into non-native language) as a viable alternative to the indirect translation. In the case of Ukrainian being the source language the most widespread mediating language was Russian. The causing factor was not the "prestige", proposed by G. Toury for some translations into Hebrew, which were done through German, Russian and English [11, p.142] but as an act of censure by the Soviet Union. Hence, the practice of translating Ukrainian literary works into other European languages through Russian was always concealed or presented as a beneficial act. For example, P. Zaborov in the article on Zwischenübersetrung (mediated translation) states that Russian mediation opened the passage abroad to the majority of "national cultures" [13, p. 2072]. A very similar opinion expresses Clifford E. Landers in his book on literary translation (2001): "it's safe to say that certain classic works of world literature would not have found their way into languages of limited diffusion had it not been for indirect translation (Shakespeare in Afrikaans or Basque etc.)" [5, p. 130-131]. M. Ringmar states that very often for writers, who write in peripheral languages, the only alternative to the indirect translation is the absence of translation [10, p. 142]. Thus, the common argument supporting the practice of indirect translation would be that the representatives of the peripheral source culture should be willing to embrace the indirect translation for the greater good (being known or represented abroad etc.).

However good indirect translation illustrates the functioning of translator disparity, another critical element to its functioning is the agent of translation - a translator. In the last decade the role of a translator has gained significance in the realm of Translation Studies. In 2010 M. SnellHornby outlined three turns in Translation Studies: cultural, globalization and empirical [11, p. 267-268]. She stated that despite all the expectations the sociological turn in Translation Studies has never occurred. R. Jääskeläinen on the contrary outlines the sociological turn of Translation Studies, which "creates an interface with translation psychology (translation ethics, agency etc.)" [8, p. 196]. In 2009 A. Chesterman offered an "agent model" of translation, which represents a division of Translation Studies into Textual and Translator Studies, which encompasses cultural, cognitive and sociological subfield's, covering Holmes's model of 1988 [4, p. 14]. Analysing the new tendencies in Translation Studies, M. Baker also states that there has been the shift of focus from textual materials to different agents, which "produce translated texts and mediate oral interaction" [2, p. 15]. In his book "On translator ethics: Principles for mediation between cultures" (2012) A. Pym focuses on the role of translator (translator as a 
missionary, messenger etc.), translator's position (the intercultural space of the translator) and translator's responsibility. "The translator's responsibility cannot be limited to the laws of a receiving society. It must be formulated and maintained according to standards that are as intercultural as the translator's work itself' [9, p. 57]. Therefore, translator's responsibility lies in the representation of translated material. Thus, the overlap of the narrative theory of translation and Translation Studies becomes evident. M. Baker argues that translator intrudes into the narrative, S.-A. Harding states that translators "passively or actively, consciously or subconsciously, take part in re-narration" [5, p. 108], as in developing, continuing or changing the existing narrative. Hence, framing, being the product of translator decisions, is also the element of responsibility and, thus, represents a part of translator ethics. Moreover, narrative framing correlates to the "translation pact" [1, p. 270] since the perception of "the translated text as the author's even when the discursive presence of the translator is obvious" [1, p. 274] can be hampered by a certain framing.

The above mentioned concepts of the sociological and narrative approaches to translation (translator ethics, translator responsibility, narrative framing, translation pact etc.) gain special status when considering Ukrainian literature in translation. They shape translator disparity since the "peripheral" status of Ukrainian language and literature créates possibility of indirect translation or translation from the standpoint of "alternative to no translation". It entailes inequality of requirements to translator from Ukrainian in comparison to translator requirements for translation situations with global languages being source languages. Translator disparity is the byproduct of the hegemony of some languages and literatures over other. Examples of translations of Ukrainian literary prose into English and German are used in this article to illustrate translator disparity in all of its facets, taking into consideration its benefits, shortcomings, dangers and prospects.

In 1975 the publishing house "Svoboda Press" (New Jersey, USA) published comparative texts of Vasyl Symonenko's works and their English translations ("Granite Obelisks", 1000 copies). On the book's cover one can read that the selection and translation of works was done by A. Fr.-Chyrovsky. There is also the translator's dedication to the God, Ukraine, Vasyl Symonenko and Chyrovsky's parents, who helped him a lot. This short paratext puts the translation pact into danger because a reader can become suspicious of the translator's level of competence and knowledge. On the last pages of the book we find short information about the translator: he is a student (19 y. o.) of Ukrainian Catholic University in Rome, Italy. That information contains also some data about his family (father is a professor at Seton Hall and mother is a librarian and an author). The main aim of the paratext is to confirm the translation pact by persuading the target reader that the translator can be "trusted". There is also additional information about Chyrovsky's hobbys, which are writing music and poetry. Thus, the translator's telos becomes familiar to missionary work, motivated by "symbolic capital" working in order to achieve fame [9, p. 130].

Short prose by Vasyl Symonenko is quite similar to his poetry in terms of being full of metaphors, epithets and symbolism:

1. Дівчина задерла голову, ніби хотіла протаранити очима їх клубчасту похмурість. Довгими віями вона торкалася країв хмар, а ії очі були єдиними синіми цятками серед передгрозової сірости [12, p. 90]

1.2. The girl threw back her head, as if she wanted to ram through the whirling sullenness with her eyes. She touched the edges of the clouds with her long lashes, and her eyes were lone blue spots amidst the threatening grayness [12, p. 91]

2. Вона метнула на нього дві сині блискавки.

- Чому ти весь час дивишся в землю?

Він важко, мов гирі, підняв свої очі і спідлоба глипнув на неї, але за мить його очі знову впали в траву.

- Це не має значення, куди я дивлюся.

- Ти ніколи не дивився мені в очі. Ти завжди був жадібним і нетерплячим,- розстрілювала вона його сумніви. - Ти не хотів бути щасливим зі мною, ти просто хотів ощасливити мене [12, p. 90,92]

2.1. She whipped her two blue lightning bolts at him.

"Why do you look at the ground all the time?"

He lifted his eyes laboriously, as if weights, and looked sullenly at her, but in a moment his eyes fell on the grass again.

"It's meaningless where I look."

"You never looked in my eyes. You were always greedy and impatient," she executed his doubts. "You didn't want to be happy with me, you only wanted to make me happy."'[12, p. 91,93]

In the sentences from examples 1 and 2 we can see that eyes represent the main symbol and metaphors serve as character indicators in the text. In the example 1. протаранити очима їх клубчасту похмурість and віями вона торкалася країв хмар denote a touching determination of the girl in the face of передгрозової сірости (grayness before the storm) - an epithet, symbolizing difficulties, especially relationship related. In the example 1.2. we can see that the first two metaphors were rendered using calque translation, whereas the epithet was explicated in English (threatening grayness), which saturates the original image and creates anticipation of something bad happening in the future. However, that anticipation will be defeated since there won't happen anything of that kind in the story. Thus, translation being over metaphorical can be redundant since it creates a false expectation on the reader's part.

In the example 2 we can observe the development of metaphorical images: “сині цятки” (blue spots) from the example 1 turn into “сині блискавки” (blue lightnings), which is rendered in the English translation. The translator uses calque translation when rendering simile мов гирі, підняв свої очі (He lifted his eyes laboriously, as if weights). The metaphor розстрілювала вона його сумніви in the English translation becomes she executed his doubts, which has a weaker level of emotional sharpness. Alternative translation would be she fired away/off his doubts.

The following examples illustrate a few contentious translation decisions:

3. Десять хвилин бігали зморшки по чолах, десять хвилин стікало мовчанням сонце, десять хвилин задубілими очима вдивлялися люди в закручений шпориш, ніби хотіли віднайти в ньому якийсь порятунок. Потім натовп заворушився, i озерце людей вих- 
люпнуло наперед, тисячолітнього Опанаса Крокву [12, p. 94]

3.1. Ten minutes the wrinkles ran across their foreheads, ten minutes the sun ran down in silence, ten minutes the people peered with stiffened eyes at the curled grass, as if they wanted to find salvation in it. Then the crush stirred and the little lake of people splashed up a thousand-year-old Opanas Krokva [12, p. 95]

Metaphor бігали зморшки по чолах was rendered by calque translation (the wrinkles ran across their foreheads), whereas стікало мовчанням сонце (the sun was bleeding in silence) is translated as the sun ran down in silence. The change of image is an implication of poetic inclinations of the translator. The third metaphor from the example 3 озерце людей вихлюпнуло remained unchanged in the translation - the little lake of people splashed up. Thus, the translator calqued the image of the metaphor again.

Therefore, A. Fr.-Chyrovsky renders the symbolism of
V. Symonenko's works by adhering to calque translation mostly. However, impropriety of some translation decisions (explications, non-motivated image changes) are hard to justify, which can be attributed to the lack of experience on the part of the agent of translation.

Thus, translator disparity bestows a certain kind of freedom on the translator, perhaps even immunity against the possible criticism, which entails the danger of excessive freedom, given to a translator (translation done by an unprepared person etc.). Should the "small" languages and literatures turn a blind eye to such cases? The eternal alternative of "not being translated at all" seems to function as an intimidation, evoking translator disparity, which can potentially lead to negative consequences (e.g. low requirements to a translator can cause a low quality translation etc.). Intellectual property of the country is the main indicator of its identity and its representation on the international arena deserves great attention irrespective of its language status and popularity.

\section{REFERENCES}

1. Alvstad Cecilia. The translation pact // Cecilia Alvstad // Language and Literature. Journal of the Poetics and Linguistics. Special issue: Narration and Translation; [editor: Geoff Hall; assistant editors: Catherine Emmott, Joanna Gavins]. - London: Sage Publications Ltd., 2014. - Vol.23. - №3. - P. 270284.;

2. Baker Mona. The Changing Landscape of Translation\&Interpreting studies / Mona Baker. - 2014. - 23p.https://www.academia.edu/6311299/The_Changing_Landscape _of_Translation_and_Interpreting_Studies;

3. Bellos David. Is that a Fish in your Ear? The Amazing Adventure of Translation/ David Bellos. - London: Penguin Books Ltd, 2012. -390 p.;

4. Chesterman Andrew. The Name and Nature of Translator Studies / Andrew Chesterman// Hermes - Journal of Language and Communication Studies, 2009. - n.42. - P.13-20. http://download1.hermes.asb.dk/archive/download/Hermes42chesterman_net.pdf;

5. Clifford E. Landers. Literary Translation: A practical guide/ E. Landers Clifford. - Cleveden, Buffalo, Toronto, Sydney: Multilingual Matters LTD, 2001. - 214 p.;

6. Harding Sue-Ann. Narratives and contextual frames / Sue-Anna Harding // Handbook of translation studies; [edited by Yves Gambier, Luc van Doorslaer]. -Amsterdam/ Philadelphia: John Benjamins Publishing Company, 2013. - V.4. - P.105-111.;

7. Havryliv Tymofiy. Übersetzungen aus dem Ukrainischen ins Deutsche, 1991 bis heute. Eine Studie von Nächste Seite Foundation im Rahmen des Buches Platform-Projekt / Tymofiy Havryliv. $\quad-\quad 2013 . \quad-\quad 20 \quad$ s. http://translate.google.de/translate?hl=de\&sl=uk\&u=http://ww w.bookplatform.org/uk/activities/484-ukrainian-to-german-

translations-study.html\&prev=search;

8. Jääskeläinen Riitta. Translation psychology / Riitta Jääskeläinen // Handbook of translation studies; [edited by Yves Gambier, Luc van Doorslaer]. -Amsterdam/ Philadelphia: John Benjamins Publishing Company, 2012. - V.3. - P.191-197.;

9. Pym Anthony. On Translator Ethics. Anthony Pym; translated by Heike Walker, revised and updated by the author. - Amsterdam/ Philadelphia: John Benjamins Publishing Company, 2012. - 185 p.;

10. Ringmar Martin. Relay translation / Martin Ringmar // Handbook of translation studies; [edited by Yves Gambier, Luc van Doorslaer]. -Amsterdam/ Philadelphia: John Benjamins Publishing Company, 2012. - V.3. - P.141-144. ;

11. Snell-Hornby Mary. The turns of Translation Studies / Mary Snell-Hornby // Handbook of translation studies; [edited by Yves Gambier, Luc van Doorslaer]. -Amsterdam/ Philadelphia: John Benjamins Publishing Company, 2010. - V.1. - P.366370 ;

12. Symonenko V. Granite Obelisks / Symonenko V.; selection, translation and explanation by A. M. Fr.-Chyrovsky. - New Jersey: Svoboda Press, 1975. - 143 p.;

13. Zaborov Petr. Die Zwischenübersetzung in der Geschichte der russischen Literatur / Petr Zaborov // Übersetzung. Translation. Traduction. Ein internationales Handbuch zur Übersetzungsforschung. An international Encyclopedia of Translation Studies. Encyclopidie internationale de la recherche sur la traduction; [herausgegeben von Harald Kittel, Armin Paul Frank, Norbert Greiner, Theo Hermans, Werner Koller, Jose Lambert, Fritz Paul; in Verbindung mit Juliane House etc.]. - Berlin/ Boston: Walter de Gruyter, 2011. - Teilband 3. - S. 20682074.

\section{Исследуя переводческий диспаритет \\ Б. О. Плющ}

Аннотация. В статье рассматривается переводческий диспаритет как понятие, свойственное переводу так называемых малых литератур. В ней также исследуется роль переводческого диспаритета в представлении украинской художественной прозы, ф также его корреляция с такими маргинальными практиками перевода как непрямой перевод. Украинская литература является иллюстративным материалом этой статьи поскольку украинский язык не принадлежит к распространенным языкам или часто изучаемым в качестве иностранного носителями английского языка.

Ключевые слова: перевод, переводческий диспаритет, непрямой перевод, этика переводчика, ответственнойсть переводчика, паратексты. 